\title{
Perceptions of Auditing and the Provision of Non-Audit Services: Case Study in Libya
}

\author{
Nedal Sawan ${ }^{1}$, Abdulaziz Alzeban ${ }^{2} \&$ Khaled Hamuda ${ }^{3}$ \\ ${ }^{1}$ Liverpool Business School, United Kingdome \\ ${ }^{2}$ King Abdulaziz University, Saudi Arabia \\ ${ }^{3}$ Al-Aziza Institute, Libya \\ Correspondence: Nedal Sawan, Liverpool Business School, United Kingdome. E-mail: ne2000dal@hotmail.com
}

Received: May 13, 2013 Accepted: June 7, 2013 Online Published: June 26, 2013

doi:10.5539/ijbm.v8n14p168 URL: http://dx.doi.org/10.5539/ijbm.v8n14p168

\begin{abstract}
This paper examines whether non audit service are associated with audit quality. In relation to the impact of non-audit service on audit quality, the provision of NAS to audit clients was found to provide auditors with greater experience of the client's industry and greater access to the client's accounting system. Additionally, such an arrangement was considered to enhance audit quality, but simultaneously it was also believed that a separation of NAS from audit services was desirable since auditors are perceived to have greater credibility when the demarcation is clear. A questionnaire was used to collect data. To confirm and support the questionnaire findings semi-structured interviews were conducted the data used for this study was collected from two sources: the demand side (Libyan oil companies) and the supply side (audit firms working in Libya).
\end{abstract}

Keywords: auditor independence, audit quality, non-audit service, oil company, audit firms

\section{Introduction}

The non-audit service by incumbent auditors has been intensively debated in the literature. Since the early 1980s, the work undertaken by audit firms has gradually changed such that the revenue from audit services has fallen, while that from the provision of other services has increased (Abu Bakar et al, 2005; Abdel-Khalik, 1990; Craswell, 1999; DeFond et al, 2002; Firth, 1997a). This trend has caused some major worries, concerned with the pricing of individual services where the auditor performs several different services, and there is potential for compromising auditor independence. The AICPA defines Non-Audit Service (NAS) as: “...the function of providing professional advisory (consulting) services, the primary purpose of which is to improve the client's use of its capabilities and resources to achieve the objective of the organisation" (cited in Patten and Nuckols, 1978).

\section{Literature Review}

Although there have no studies recently dealing with the relationship between non-audit service and audit quality in Libya, however, the topic still raises interest and calls for further and more in-depth research. The following provides an overview of the key literature in order to gain a deeper understanding of the topic under consideration.

There has been extensive debate (e.g. Barkess and Simnett, 1994; Canning and Gwilliam, 1999; DeFond et al, 2002; Firth, 1997a) on the merits of audit firms providing non-audit services, the main concern being that NAS is normally expressed in terms of economic dependency and mutuality of interest, and this is why audit fees must be disclosed in annual reports. If NAS become sufficiently important, either in total or in relation to an individual client, the economic dependence of the audit firm on these services and clients may result in the loss of impartiality and objectivity (Simunic, 1984).

\subsection{Arguments against the Provision of Non-Audit Services (NAS)}

Much public interest has arisen in the provision of NAS (Simunic, 1984), and as noted by Craswell (1999), regulators internationally have considered the potential problems it can cause. Actually, Beattie and Fearnley (2002) found no evidence to support the contention that the provision of audit and NAS resulted in decreased audit quality, but they did confirm that it might adversely affect the perception of audit independence because suspicions are, that where an audit firm acts as both consultant and auditor, there may be an incentive not to report any 
shortcomings in consultancy advice which have been discovered during the course of the audit in order to avoid damage to its reputation (Simunic 1984).

Additionally, the economic relationship between the audit client and the auditor may be such that the auditor will ignore dubious management accounting practices since the act of calling these practices into question could result in the loss of the current audit fee as well as any future NAS undertakings. Another disadvantage of providing NAS to audit clients occurs when NAS provide auditors with client-specific rents, in which case companies may be able to obtain more favourable financial reports by threatening to switch auditor.

The potential for public perception of impaired auditor independence when a firm provides both audit and NAS is confirmed by several researchers (Hay et al, 2006; Simunic, 1984, Beck et al, 1988a, Canning and Gwilliam, 1999; Craswell, 1999; Abu Bakar et al, 2005; Alleyne and Devonish, 2006), who note that the high fees involved suggest too great a mutual reliance between auditor and auditee. However, as noted by Mautz and Sharaf (1961) half a century ago, the interests of auditor and auditee become the same when both audit and NAS are provided, and this inevitably leads to an end to the accountant's independence. Consequently, they advocate the use of auditors for auditing purposes only, and the complete separation of audit and NAS. Clikeman (1998) echoes these arguments, confirming that the provision of NAS requires the provider to be an ally of management, whereas the provision of audit services demands total professional detachment from management.

Clearly, this is a very difficult position to achieve because, as argued by DeBerg et al (1991), the economic bond between auditor and client is strengthened by the provision of both audit and NAS, and as Largay (2002) observes, with a significant growth in this respect, auditors may become more willing to protect clients in order to avoid dismissal and lose fees. Such assumptions have been tested by Firth (2002) who took a sample of 1,112 non-financial companies listed on the international stock exchange, and found there was indeed a link between clean audit reports and high NAS fees.

Nonetheless, it was acknowledged by Firth (2002), that the findings were inconclusive since other variables may have caused the result, such as for instance, extra NAS may have been employed by a struggling company in order to help clear up problems it was facing, and the consequent resolution of those problems by the auditor could result in a genuinely clean audit report. In such cases, NAS are helpful to the audit process (Firth 2002). Lennox (1999b), however, argues that NAS have both benefits and disadvantages because whilst they increase the likelihood of problems being found, they also enhance the probability of reducing auditor independence.

It is obvious that the provision of both audit and NAS may well result in a conflict of interests because of the economic relationship, which could easily lead to the client's expectation that the auditor will be amenable to compromise. Indeed, Flint (1988: 81) argues that "the auditors may become unduly sympathetic to a directorial or managerial attitude or interpretation of events, or the work may involve the creation of systems and information rather than assessing the adequacy of the systems and information which have been created by the directors or managers".

Because of these strong potential problems, Lee (1993) stresses the need for total impartiality and the need to make decisions without considering potential adverse financial results, when both audit and NAS are commissioned.

Many researchers argue that it is not possible for this level of objectivity to be sustained (Brandon et al, 2004; Frankel et al, 2002; Glezen and Millar, 1985; Jenkins and Krawczyk, 2001; Lowe and Pany, 1995; 1996; Raghunandan, 2003; Wines, 1994) because the auditors would in effect be auditing their own work, and perhaps acting in management role. The strong economic bond is believed to affect "their mental attitude, impartiality and objectivity, and independence of thought and act" (Flint, 1988:82), heightening the risk that auditors may surrender to management pressure when they provide ongoing NAS (Antle, 1984; Canning and Gwilliam, 1999; DeAngelo, 1981a; Magee and Tseng, 1990; Simunic, 1984). Indeed, Brandon et al (2004) found a negative relationship between the size of NAS fees paid to external auditors and a firm's bond rating.

Recent research (Felix et al, 2005) confirms that the amount of client pressure upon auditors providing them with NAS increases, and that auditors become less concerned with the quality of internal audits, and are subsequently influenced in decisions made when collecting audit evidence. Indeed, Quick and Ben-Rasmussen (2005) found from their questionnaire survey with state authorised auditors, managing directors, bank loan officers, private shareholders and business journalists, that produced a response rate of $73.1 \%$, that all of the groups of respondents with the exception of auditors themselves and managing directors, perceived auditor independence to be impaired when both audit and NAS are performed for a particular client. That said, the researchers do point out that because auditors do not consider their provision of NAS to impair their independence, "independence in mind is not affected" (Quick and Ben-Rasmussen 2005:148). However, in this study, NAS were treated broadly and as there is a possibility that specific NAS may have different effects upon auditor independence, future research should 
concentrate on different types of NAS.

Finally, Gaynor et al (2006), studying audit committee members, demonstrate that the provision of NAS has definitely been held to damage independence, because since the 2002 SEC ruling that audit committees must pre-approve and disclose all NAS provided by their regular auditor, the audit committee members are less likely to allow joint provision of both audit and NAS, even if these services actually improved audit quality. Given that it is the responsibility of audit committees to maintain investor trust, they are reluctant to allow both audit and NAS to be conducted by the same firm as they recognise completely the inherent contradiction in the role and expectations of the auditor.

\subsection{Arguments in Favour of the Provision of Non-Audit Services}

As already seen, contrasting findings do show that there is no detrimental effect on audit quality and audit independence (Antle et al, 1997; Glezen and Millar, 1985; Gul, 1989; Raghunandan, 2003; Scheiner, 1984), but nevertheless, many countries prefer the relevant professional bodies to acknowledge the potential conflict and formulate guidelines (Lee, 1993). Researchers who support the provision of joint services argue that this arrangement ameliorates audit independence (Antle et al, 1997), because it provides the auditor with better knowledge of a client (through 'knowledge spillover'), and may well enhance the likelihood of problem discovery, and hence audit quality (Goldman and Barlev, 1974; Wallman, 1996). Another argument is that the switching of auditors creates disharmony since the close relationship between auditor and client is lost in the process.

Indeed, Hartley and Ross (1972) found from their survey that only $6 \%$ of respondents considered the provision of NAS as negatively affecting auditor independence. Likewise, Firth (1980) argues that the provision of NAS causes an insignificant risk to auditor independence, and in research conducted by Glezen and Millar (1985), it was found that stockholders were not concerned about the joint provision of audit and NAS. Palmrose's (1988) study of US corporations showed that they preferred to use their commissioned audit firms for NAS, irrespective of the amount of NAS involved, and there was no perceived risk to auditor independence.

Svanström and Sundgrenwe (2012) confirm a positive association between perceived quality of audit services and the likelihood of a client purchasing non-audit services from the auditor.

Gul (1989) actually found that New Zealand bankers perceived the effects of NAS as being a positive influence on auditor independence, and Moizer (1997) considered that a direct, positive relationship existed between an audit firm's economic interests in a client and that client's dependence on it. Further, Hussey (1999) indicated that financial directors in the UK were in favour of the provision of NAS to audit clients. Many benefits such as a reduction of total costs, increased technical auditing quality, and enhanced competition are cited (Arrunada, 1999; Goldman and Barlev, 1974; Wallman, 1996), all of which could improve audit quality, and lead to cost savings in both markets (audit and NAS) which could be passed on to the customer.

Furthermore, the provision of NAS results in an increase in client- and firm-specific assets, which always have a positive effect on independence. Another perceived advantage (Grout et al, 1994), is the potential for auditors to diversity their portfolio of activity, which ultimately results in a reduction on their reliance on a single customer.

It is also noted that the provision of NAS can allow audit firms to develop their capabilities and reputation. Antle (1999) argues that the incentive to sell on profitable non-audit services prevents auditors being dishonest, and De Fond et al (2002) confirm that it is against the best interests of the auditor to sacrifice his/her audit quality in order to enhance a consulting relationship. Moreover, there is a greater risk that government will bring in producing legislation relating to self-regulation if audit firms damage their reputation and thus reduce the credibility of the profession as a whole (Hillison and Kennelly, 1988). Frankel et al (2002) suggest that an auditor's reputational capital can be enhanced by the provision of NAS, and consequently the auditor would not be prepared to jeopardise this in surrendering to any particular client's demands to overlook financial problems.

The economic theory of auditor independence that postulates the potential for compromise of independence where incentives to do so are present, was tested by Chung and Kallapur (2003), who used a sample of proxy statements from 1,871 Big Four clients, to determine ratios of client fees to total audit firm revenue (to establish economic dependence) and the ratio of the clients' NAS services fees to total audit firm revenues. Regression techniques revealed no association between abnormal accruals and the client importance ratios, providing evidence that is inconsistent with the economic theory of auditor independence, but that is in line with the arguments of Goldman and Barlev (1974), who assert that NAS increase an auditor's value to the client, thereby placing the auditor in a stronger position to resist client pressure. Chung and Kallapur (2003) obtained similar findings to those of Mitra (2007), who conducted a cross-sectional regression analysis of abnormal accrual adjustment of oil and gas companies, finding that abnormal accrual adjustments were not related to fees paid for NAS. Mitra (2007) argues 
that industry specialisation and reputation protection are sufficient incentive to ensure auditors remain independent and that they actually strengthen independence. All of these research studies, concur with the review of the NAS literature made by Francis (2006), that suggests there is no direct evidence that audit quality is compromised by the provision of NAS to audit clients. Santan (2007), in a recent study, also finds no support for the SEC's contention that the provision of NAS places audit quality and auditor independence at risk.

\section{Methods and the Sampling Unit}

A mixed methods approach was utilised in this study to gather a range of views from all the professional groups involved in Libyan Auditing. Questionnaires were used to collect data concerning the perceptions of two sources: the demand side (Libyan oil companies) and the supply side (audit firms working in Libya). The data for the Libyan oil companies was gathered from three different types of respondents: internal auditors, financial managers and accounts managers. The reason for choosing these three groups of respondents, rather than other employees in the company, was the fact that the literature of auditing indicates that the external auditor usually has more contact with these groups than any others. For the audit firms, data was gathered from employees at all levels in the audit firm: managing partners, audit supervisors and auditors.

The rationale for choosing oil companies was because of their high level of organisation and the fact that most of these companies employ staffs who hold degrees from the United States or Britain - these two facts enabled the researcher to access the right people and obtain the appropriate data.

The magnitude of the activities of the oil companies, and hence the scale of the accounting systems, represent an attraction for large numbers of qualified accountants, who hold qualifications and different accounting backgrounds, a fact that allowed the researcher to have access to a large community of accountants, with diverse careers and work experience.

In order to refute and support the questionnaire findings, semi-structured interviews were conducted. The sample for the interviews was broadly similar to the sample for the questionnaire, which involved a sample from Libyan oil companies, namely, internal auditors, financial managers, accounts managers, and a sample from audit firms working in Libya, namely, managing partners, auditors and audit supervisors. Regulators working in the LAAA were also included in the sample of the interviews, partly due to the fact that, after analysing the questionnaire survey, the researcher found it necessary to interview regulators to clarify some grey areas found in the analysis, and more importantly, to triangulate the sample of the study and to obtain different opinions from different dimensions. The total number of interviews conducted with the oil companies was ten (three with internal auditors, four with financial managers, and three with accounts managers), and the total number of interviews conducted with the audit firms working in Libya, was thirteen (four with managing partners, six with audit supervisors, and three with auditors). Lastly, two interviews were conducted with regulators working for the LAAA. This process aims to enhance and supplement the questionnaire findings providing an in-depth clarification and understanding of the effects that the selected factors have on evidence obtained by Libyan auditors. Content analysis was used to analyse the collected data from the interviews.

The first part of the questionnaire was designed to obtain the views of external, internal, state and taxation auditors relating to the effects of the professional and academic qualifications of the auditor on quality of evidence. The second section aimed to gather the participant's opinions regarding the effects of the consistency of evidence on audit evidence. The final section asked the participants about the effects of amount of evidence on quality of evidence.

A 5-point Likert-scale ranging from strongly undermines evidence to strongly enhances evidence was utilised to measure perceptions regarding quality of audit evidence (Saunders et al., 2007).

For the purpose of this study, 147 questionnaires were distributed to the oil companies. Of these, 52 went to Internal Auditors, 50 to Financial Managers, and 45 to Accountants Managers. Additionally, 300 questionnaires were sent to the audit firms working in Libya, 100 to Managing Partners, 100 to Audit Supervisors and 100 to Auditors. The samples from the demand side (internal auditors, financial managers and accounts managers), represent the agent of the principal, and conduct business on behalf of the principal. Hence, a monitoring mechanism is needed to assess their performance (Jensen and Meckling, 1976). The samples from the supply side (managing partners, audit supervisors and auditors), represent the main subjects of the issue of interest who provide certification and/or information credibility assessment to the stakeholders (Humphrey, 1997). Hasan (2000) point out that audit firms and their clients evaluate audit quality in different ways, and it was, therefore important to receive responses from both sections of the research population.

Considerable effort was made in order to avoid problems of non-response and to ensure the completeness of the 
questionnaire which, was designed using mainly closed questions which are easy for respondents to answer. The questionnaire sample consisted of all listed oil companies in the NOC and 100 audit firms working in Libya. According to the pilot study results, the wording of the questionnaire was clear and straightforward, the instrument was of a reasonable length, and there were no complaints about layout. Most of the questionnaires were personally administered (Managing Partner - 52 questionnaires, Audit Supervisor - 52 questionnaires, Auditor - 56 questionnaires, Internal Auditor - 45 questionnaires, Financial Manager - 47 questionnaires, and Accounts Manager - 35 questionnaires), and some questionnaires were delivered personally by the researcher and returned by mail. Therefore, anonymity and other ethical considerations relating to mailed questionnaires were avoided as far as possible.

The overall response rate to the questionnaire was extremely encouraging at 64\% (see Table 1). Remenyi et al. (2002) suggesting that a response rate above $60 \%$ is considered to be exemplary. The response rates for Internal Auditors and Financial Managers were $86.5 \%$ and $94 \%$ respectively, higher than those of Accounts Managers, Managing Partners, and Audit Supervisors, which were $77.7 \%, 52 \%$ and $52 \%$ respectively. Some were unable to complete the questionnaires, and the researcher was unable to contact respondents outside Tripoli because of poor communication facilities, included in which is the official postal system.

Table 1. Questionnaire survey response rate

\begin{tabular}{cccc}
\hline Group & Distributed questionnaires & Useable questionnaires & Response rate \\
\hline Managing Partner & 100 & 52 & 52 \\
Audit Supervisor & 100 & 52 & 52 \\
Auditor & 100 & 56 & 56 \\
Internal Auditor & 52 & 45 & 86.5 \\
Financial Manager & 50 & 47 & 94 \\
Accounts Manager & 45 & 35 & 77.7 \\
Total & 447 & 287 & 64 \\
\hline
\end{tabular}

\section{Results and Discussion}

\subsection{Quantitative Findings}

The analysis of respondents' perceptions about the relationship between the provision of NAS and audit quality. It shows that $84.2 \%$ of oil company respondents either agreed or strongly agreed with the statement the provision of NAS to an audit client gives the auditor more experience of the client's industry and more access to the client's accounting system. This statement achieved the highest mean score (4.24). Providing NAS to an audit client by a separate department gives the auditor more credibility had the highest second mean score (3.50), with $(60.7 \%)$ of oil company respondents either agreeing or strongly agreeing with it. This result might reflect the respondents' confidence in the safeguards of auditor independence from the segregation of duties by splitting the provision of audit and NAS into separate departments, which is consistent with the arguments proposed by Canning and Gwilliam (1999) and Pany and Reckers (1984).

Sequentially, the third highest mean score (3.39) was achieved by the statement the prohibition of the provision of NAS to an audit client is only to maintain the perception of independence. Again, $48 \%$ either agreed or strongly agreed with it. The statement with the fourth highest mean score (3.20) was the provision of NAS to an audit client reduces the probability of switch threat change auditor, with half $(50.4 \%)$ of respondents either agreeing or strongly agreeing with it.

In contrast, a third of the oil company respondents (33.1\%) either agreed or strongly agreed with the statement the provision of NAS to an audit client leads to economic dependency on that client and causes a conflict of interests for the auditor. It achieved the lowest mean score of (2.50). The statement with the second lowest mean score 2.83 ) was the provision of NAS impairs audit quality, with which $23.7 \%$ of respondents either agreed or strongly agreed.

The statement with the third lowest mean score (3.04) was only a certain type of NAS impairs audit quality. Over a third $(45.7 \%)$ of respondents either agreed or strongly agreed with this statement.

With regard to responses from the audit firms, Table 2 shows that the statement the provision of NAS to an audit 
client gives the auditor more experience of the client's industry and more access to the client's accounting system, achieved the highest mean score of 3.98 , with $72.5 \%$ of respondents either agreeing or strongly agreeing.

The statement with the next highest mean score (3.58) was the prohibition of the provision of NAS to an audit client is only to maintain the perception of independence, which gained either agreement or strong agreement from $58.8 \%$ of respondents. The statement the provision of NAS to an audit client reduces the probability of a threat to switch auditor achieved a mean value of (3.53), with just over half (51.9\%) of respondents either agreeing or strongly agreeing with it. The statement with the fourth highest mean score (3.34) was Providing NAS to an audit client by a separate department gives the auditor more credibility. Just under half $(47.5 \%)$ of respondents either agreed or strongly agreed with this statement, possibly reflecting the confidence of the respondents from large audit firms and local firms in their ability to separate their staff according to the type of services they were commissioned to perform. Indeed, the provision of NAS by staff from separate departments has been practised by large audit firms for decades.

In contrast, the statement with the lowest mean score (2.43) was the provision of NAS impairs audit quality, which attracted agreement or strong agreement from only $16.9 \%$ of respondents.

The statement with the second lowest mean score (2.57) was the provision of NAS to an audit client leads to economic dependency on that client and causes a conflict of interests for the auditor. Just less than a third (30\%) of respondents either agreed or strongly agreed with this statement. The statement with the third lowest mean score (3.26) was only certain types of NAS impair audit quality and in this respect, $48.8 \%$ of audit firm respondents either agreed or strongly agreed with it.

Since the overall responses of oil companies and audit firms were not completely identical, an attempt was made to isolate the determinants of the disparities. Therefore, the extent to which position and type of audit firm might explain differences in oil company and audit firm respondents' opinions, was once again tested using the Kruskal-Wallis and Mann Whitney U tests.

Table 2, which documents the results, shows two significant differences at the $1 \%$ level, as measured by the Mann Whitney U test.

On examination of the level of agreement, oil company respondents were significantly higher than audit firm respondents in respect of the statement that the provision of NAS impairs audit quality. This difference in the responses is interesting, and perhaps suggests that audit firm respondents viewed the provision of NAS from the profit perspective, whereas oil companies viewed the provision of NAS as not impairing audit quality, but needing some restriction.

The level of agreement from oil company respondents was significantly higher than that from audit firm respondents in respect of the statement highlighting the advantages of the provision of NAS to an audit client as being that it gives the auditor more experience of the client's industry and more access to the client's accounting system. This result might reflect a preference of oil company respondents to receive the provision of NAS from their external auditor.

However, in general, the above results are consistent with prior literature (Abdel-Khalik, 1990; Craswell, 1999; De Fond et al, 2002) that identifies the provision of NAS to audit clients as having the potential to increase the auditor's client knowledge, and therefore, enhance the probability that problems would be discovered. Therefore, for a given level of independence, NAS may increase audit quality. Further, NAS may increase a client's dependence on its auditor, thereby reducing the credibility of the switch threat. Another commonly-mentioned advantage of providing NAS to audit clients is the potential cost advantage to the client arising from knowledge spillovers, which are transfers of knowledge that may occur when NAS are provided by the incumbent auditor. 
Table 2. Distribution of the evaluations given by the different statements regarding the Non-Audit Services (NAS) and audit quality

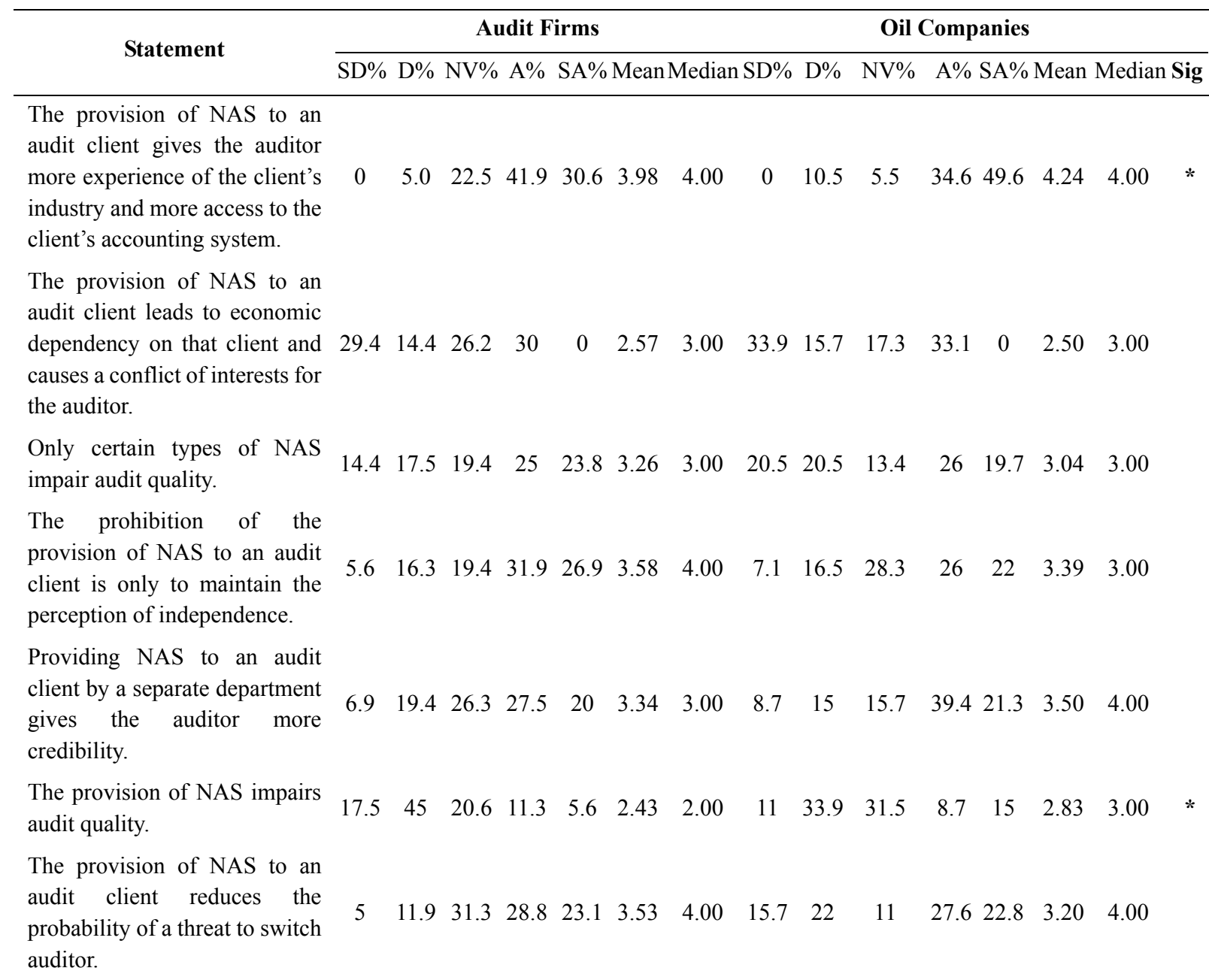

*** indicates distribution of responses is significantly different at the $1 \%, 5 \%$ levels, respectively using the Mann Whitney $U$ test.

\subsubsection{The Perceptions of NAS Based on Position}

Table 3, shows that when comparing the responses of oil company staff and audit firm staff using the KruskalWallis test, one significant difference (at the $5 \%$ level) is observed. Financial managers, accounts managers and internal auditors had significantly higher mean scores (4.32, 4.31 and 4.09) than audit supervisors and auditors (3.96 and 3.98) for the statement The provision of NAS to an audit client gives the auditor more experience of the client's industry and more access to the client's accounting system. This finding may be due to the belief of financial managers and internal auditors, who may feel that the non-provision of audit services improves audit quality, and believes that if NAS are not provided, more audit hours are needed for new auditor to become familiar with the company system. This result is consistent with that obtained by other researchers who support the provision of joint services, arguing that this arrangement ameliorates audit independence (Antle et al, 1997), because it provides the auditor with better knowledge of a client (through 'knowledge spillover'), and may well enhance the likelihood of problem discovery, and hence audit quality (Goldman and Barlev, 1974; Wallman, 1996). 
Table 3. Distribution of the evaluations given by the different statements regarding the Non-Audit Services (NAS) based on position

\begin{tabular}{|c|c|c|c|c|c|c|c|c|c|c|c|c|c|}
\hline \multirow{3}{*}{ Statement } & \multicolumn{6}{|c|}{ Audit Firm Staff } & \multicolumn{6}{|c|}{ Oil Company Staff } & \multirow{3}{*}{ Sig } \\
\hline & \multicolumn{2}{|c|}{$\begin{array}{l}\text { Managing } \\
\text { Partner }\end{array}$} & \multicolumn{2}{|c|}{$\begin{array}{c}\text { Audit } \\
\text { Supervisor }\end{array}$} & \multicolumn{2}{|c|}{ Auditor } & \multicolumn{2}{|c|}{$\begin{array}{l}\text { Internal } \\
\text { Auditor }\end{array}$} & \multicolumn{2}{|c|}{$\begin{array}{l}\text { Financial } \\
\text { Manager }\end{array}$} & \multicolumn{2}{|c|}{$\begin{array}{l}\text { Accounts } \\
\text { Manager }\end{array}$} & \\
\hline & Mean & Media & Mean & Median & Mean & Median & Mean & Median & Mean & Mediar & Mean & Median & \\
\hline $\begin{array}{l}\text { The provision of NAS to an audit client } \\
\text { gives the auditor more experience of the } \\
\text { client's industry and more access to the } \\
\text { client's accounting system. }\end{array}$ & 4.00 & 4.00 & 3.96 & 4.00 & 3.98 & 4.00 & 4.09 & 4.00 & 4.32 & 5.00 & 4.31 & 5.00 & $* *$ \\
\hline $\begin{array}{l}\text { The provision of NAS to an audit client } \\
\text { leads to economic dependency on that } \\
\text { client and causes a conflict of interests } \\
\text { for the auditor. }\end{array}$ & 2.48 & 3.00 & 2.67 & 3.00 & 2.55 & 3.00 & 2.82 & 3.00 & 2.38 & 2.00 & 2.23 & 2.00 & \\
\hline $\begin{array}{l}\text { Only certain types of NAS impair audit } \\
\text { quality }\end{array}$ & 3.50 & 4.00 & 3.23 & 3.00 & 3.07 & 3.00 & 3.24 & 3.00 & 3.09 & 3.00 & 2.71 & 2.00 & \\
\hline $\begin{array}{l}\text { The prohibition of the provision of NAS } \\
\text { to an audit client is only to maintain the } \\
\text { perception of independence. }\end{array}$ & 3.88 & 4.00 & 3.29 & 3.50 & 3.57 & 4.00 & 3.29 & 3.00 & 3.23 & 3.00 & 3.74 & 4.00 & \\
\hline $\begin{array}{l}\text { Providing NAS to an audit client by a } \\
\text { separate department gives the auditor } \\
\text { more credibility. }\end{array}$ & 3.33 & 3.00 & 3.27 & 3.00 & 3.43 & 4.00 & 3.76 & 4.00 & 3.13 & 3.00 & 3.66 & 4.00 & \\
\hline $\begin{array}{l}\text { The provision of NAS impairs audit } \\
\text { quality. }\end{array}$ & 2.27 & 2.00 & 2.48 & 2.00 & 2.52 & 2.00 & 2.82 & 3.00 & 2.72 & 2.00 & 2.97 & 3.00 & \\
\hline $\begin{array}{l}\text { The provision of NAS to an audit client } \\
\text { reduces the probability of a threat to } \\
\text { switch auditor. }\end{array}$ & 3.50 & 3.00 & 3.40 & 3.50 & 3.68 & 4.00 & 3.16 & 3.00 & 3.21 & 4.00 & 3.23 & 3.00 & \\
\hline
\end{tabular}

*,** indicates distribution of responses is significantly different at the $1 \%, 5 \%$ levels, respectively using the Kruskal-Wallis test.

\subsubsection{The Perceptions of NAS Based on Type of Audit Firms}

The analysis by type of audit firm, as reported in Table 4, shows that no significant differences were found at the $5 \%$ level, and that just one significant difference was found at the $1 \%$ level between local audit firms, local firms affiliated to an international firm, and local firms affiliated to one of the Big Four audit firms (non-Big Four and Big Four) using the Kruskal Wallis test.

The level of agreement with the statement: Only certain types of NAS impair audit quality was significantly higher from local audit firms and international audit firms (non-Big Four) (3.58 and 2.86) than from the Big Four firm respondents (2.62). This result might reflect the fact that the Big Four firm respondents believe that all types of NAS can potentially impair the level of audit quality, or pose a threat to auditor independence.

This finding is inconsistent with the reports of Abu Bakar et al (2005) and Alleyne and Devonish (2006) who found that individual non-audit services may affect auditor independence influence audit quality perceptions differently and that the provision of NAS is a significant threat to perceptions of auditor independence. 
Table 4. Distribution of the evaluations given by the different statements regarding Non-Audit Services (NAS) based on type of audit firm

\begin{tabular}{|c|c|c|c|c|c|c|c|}
\hline \multirow{2}{*}{ Statement } & \multicolumn{2}{|c|}{$\begin{array}{l}\text { Local Audit } \\
\quad \text { Firm }\end{array}$} & \multicolumn{2}{|c|}{$\begin{array}{c}\text { International } \\
\text { Audit Firm } \\
\end{array}$} & \multicolumn{2}{|c|}{$\begin{array}{l}\text { Big Four Audit } \\
\text { Firm } \\
\end{array}$} & \multirow{2}{*}{ Sig } \\
\hline & Mean & Median & Mean & Median & Mean & Median & \\
\hline $\begin{array}{l}\text { The provision of NAS to an audit client gives the auditor } \\
\text { more experience of the client's industry and more access to } \\
\text { the client's accounting system. }\end{array}$ & 4.00 & 4.00 & 4.07 & 4.00 & 3.71 & 4.00 & \\
\hline $\begin{array}{l}\text { The provision of NAS to an audit client leads to economic } \\
\text { dependency on that client and causes a conflict of interests } \\
\text { for the auditor. }\end{array}$ & 2.63 & 3.00 & 2.53 & 3.00 & 2.38 & 2.00 & \\
\hline Only certain types of NAS impair audit quality. & 3.58 & 4.00 & 2.86 & 3.00 & 2.62 & 2.00 & $*$ \\
\hline $\begin{array}{l}\text { The prohibition of the provision of NAS to an audit client } \\
\text { is only to maintain the perception of independence. }\end{array}$ & 3.63 & 4.00 & 3.56 & 4.00 & 3.43 & 3.00 & \\
\hline $\begin{array}{l}\text { Providing NAS to an audit client by a separate department } \\
\text { gives the auditor more credibility. }\end{array}$ & 3.38 & 3.00 & 3.42 & 4.00 & 3.05 & 3.00 & \\
\hline The provision of NAS impairs audit quality. & 2.39 & 2.00 & 2.58 & 2.00 & 2.29 & 2.00 & \\
\hline $\begin{array}{l}\text { The provision of NAS to an audit client reduces the } \\
\text { probability of a threat to switch auditor. }\end{array}$ & 3.50 & 4.00 & 3.63 & 4.00 & 3.48 & 5.00 & \\
\hline
\end{tabular}

*,** indicates distribution of responses is significantly different at the $1 \%, 5 \%$ levels, respectively using the Kruskal-Wallis test.

\subsection{Qualitative Findings}

The majority of interviewees did not perceive any reduction in the audit quality where NAS was provided. Indeed, they confirmed that they would have recommended their clients to use their firms for such services, arguing that the audit firm's experience and knowledge of their businesses would result in better advice being obtained. Other interviewees argued that they would prefer to see audit firms provide NAS to their clients because it would ensure that the standard applied to the audit would be higher and that a better audit opinion would result. On this issue, a Big Four managing partner remarked:

"Sometimes, yes, we suggest to clients that they come to us for NAS because accountants are the best people to provide these services because they already know that company's history and business ... and by providing NAS as well, the auditor learns more about the client and can give more informed advice."

The questionnaire survey findings, revealed that only a minority of oil company (23.7\%) and audit firm (16.9\%) respondents either agreed or strongly agreed with the statement: The provision of NAS impairs audit quality. Similarly, most oil companies and audit firms (72\%) disagreed that audit quality would be impaired if the auditor were to provide NAS to audit clients, and pointed out that both parties would benefit from the arrangement. It was indicated that the provision of NAS would complement audit duties, as the auditor would be exposed to the audit client's business transactions and subsequently gain a better understanding of the client's overall enterprise. An audit supervisor in a local audit firm affiliated to an Arab audit firm summarised the view by saying:

"If you can gain more information about your client, you can give a better audit opinion. Your appreciation of the client's business is greater so you can consider all the factors, and then provide a better service."

Moreover, a Big Four auditor commented:

"An audit could be of a higher standard overall because the auditor is also providing NAS. In this case the auditor would not want to lose the client by not giving good quality all-round service so the audit might be of an even higher standard ... but actually, the auditor knows the company better than other consultants, and it is true that the company would want someone who did know their business and their systems ... they wouldn't have to spend a long time learning everything about the company because they already have all the background."

Another local audit supervisor added:

"The auditor is in a unique position of understanding the client's financial operations and its business better than 
anybody else. I don't have any evidence that would lead me to be concerned that the audit is compromised."

A small minority of oil companies and audit firms (28\%) interviewed did, however, believe that audit quality would be impaired by the joint provision of audit and NAS to audit clients. Their argument was that auditors would build close relationships with their clients with the aim of securing other business opportunities and may use audit services as a 'loss leader' to leverage the audit services into other consulting engagements. This belief was well summarised by an internal auditor of one of the oil companies, who argued that:

"Not all the NAS can impair auditors' independence, as there are some certain types that can impair it and others would not. For instance, if the service provided is not related to decision making, independence would not be an issue."

Because the majority of interviewees had a positive attitude towards the provision of NAS by audit firms, it led to a discussion on the manner in which they perceived that such services were provided by audit firms. In all cases, they had assumed that both roles were performed by separate departments. A number of them stressed the importance of such separation as a means of ensuring that the audit quality was not compromised. The vast majority of oil companies and audit firms (96\%) interviewed agreed that audit quality and auditor independence would not be threatened if the provision of audit and NAS to an audit client was performed by staff from different departments, a perception that is consistent with the results from the questionnaire survey. The interviews disclosed that this mode of NAS provision would allow segregation of duties in monitoring activities, widely known as the 'Chinese Wall' (Mikol and Standish, 1998; Sori, 2005). It was believed that different partners would handle the different departments, which would result in greater monitoring activities and mean that the audit division might not lose sight of the material issues

On this issue, one of the auditors in one a Big Four firm remarked:

"I would be worried if NAS and audit services were being provided by the same department because this is too close, and not good for the auditor's independence, but I think this does not happen. Different departments offer these services."

The importance of the demarcation of functions was also confirmed by a managing partner of local audit firm, who remarked:

"I would see the separation of functions as very important and not prejudicing their independence ... You would assume that the audit firm is very rigorous in the separation of the two roles. You would have to have an independent person performing the audit, one separate from the person who recommended the system."

However, an audit supervisor from one of Big Four firms stressed the reality of the situation, saying:

"In the smaller firms, separation can not happen and the auditor is less reliable as a consequence ... In the larger firms, they are more specialised but in the smaller firms, you have the auditors providing a lot of tax expertise and then that is audited by them. I think that is where you have the least independence."

Also, some of the interviewees indicated that this kind of arrangement would ease information exchange, which may not be achieved if NAS were provided by other firms. Perhaps, audit firms could effectively utilise their personnel who have a good understanding of the client's business to speed up the process and subsequently produce a high quality financial statement.

In summary, it can be seen that the general consensus of opinion among interviewees was that the provision of NAS alongside audit services was only a serious threat to audit quality and independence where the two types of service were performed by the same department. However, the minority who disagreed with this perspective, believed that some types of NAS, especially those including decision-making, impaired audit quality and independence. Nonetheless, this result is not consistent with that of Shockley (1981) as his findings did not support the need for a separation of the consulting and audit function.

\section{Summary and Review of Findings}

The provision of non-audit services (NAS) that has been debated in the literature as a cause of impaired audit quality, was considered by the majority of this study's respondents not to be a serious concern, and the statement that the provision of NAS would impair the level of audit quality did not secure very much agreement. In fact, the majority of respondents believed that the provision of NAS to audit clients gives the auditor more experience of the client's industry as well as more access to the client's accounting system, thereby functioning in a complimentary capacity. Hence, such an arrangement was considered to increase the auditor's overall client knowledge, and therefore enhance the probability that problems would be discovered. In such circumstances, the provision of NAS was argued to have the potential for actually increasing audit quality. Furthermore, from the auditor's perspective, 
the provision of NAS was considered favourable, since the arrangement has the potential to increase a client's dependence on its auditor, thereby reducing the credibility of the switch threat, although such dependence, when viewed from a different perspective, could be perceived as a negative feature. Another commonly-mentioned advantage of the joint provision of audit and NAS, is the benefit arising from knowledge spillovers, which are transfers of knowledge that may occur when NAS are provided by the incumbent auditor

It was, however, agreed by the majority of the respondents that the maintenance of audit quality would require the provision of NAS to come from a separate department from the audit department. This degree of faith was interesting, and testified to the respondents' belief in the 'Chinese Wall' approach, which works to minimise communication between the audit and NAS providers despite them being under the ultimate control of the same organisation. Given that the government licenses individual auditors, and these people have to ensure that their personal image is protected, it is argued that auditors would not behave in a way as to compromise this, and in fact, welcome greater monitoring of their own activities.

The general feeling among interviewees was that they would recommend their own firms to their clients for the provision of NAS, since they believed this would not result in any reduction in the audit quality, and indeed, enhance it.

In respect of the provision of NAS, it was felt by the majority of respondents that whilst this was essentially considered by them to be a good thing, audit firms should, nonetheless, disclose the type and amount of NAS provided to their audit clients, and likewise, oil companies should disclose in their annual reports, the amount of audit and NAS fees paid. Among the standards to be set by the LAAA, should be the requirement for the separation of duties in respect of the provision of audit services and NAS, and for audit firms' percentage of NAS income from a single client not to exceed $25 \%$ of the fees obtained from that client. Additionally, the LAAA should require audit firms to disclose the type and amount of audit and NAS fees obtained from all clients.

\section{References}

Abdel-Khalik, A. (1990). The Jointness of Audit Fess and Demand for MAS: A Self- Selection Analysis. Contemporary Accounting Research, 6(2), 295-322. http://dx.doi.org/10.1111/j.1911-3846.1990.tb00760.x

Abu Bakar, N., Rahman, A., \& Rashid, H. (2005). Factors Influencing Auditor Independence: Malaysian Loan

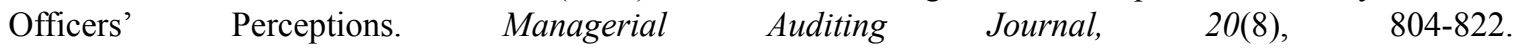
http://dx.doi.org/10.1108/02686900510619665

Alleyne, P. A., Devonish, D., \& Alleyne, P. (2006). Perceptionso f auditor independence in Barbados. Managerial auditing journal, 21(6), 621-635. http://dx.doi.org/10.1108/02686900610674898

Antle, R. (1984). Auditor Independence. Journal of Accounting Research, 22(1), 1-20. http://dx.doi.org/10.2307/2490699

Antle, R. (1999). Accounting Firms, the Accounting Industry and Accounting Research. British Accounting Review, 31(1), 1-13. http://dx.doi.org/10.1006/bare.1998.0092

Antle, R., Griffin, P. A., Teece, D. J., \& Williamson, O. E. (1997). An Economic Analysis of Auditor Independence for a Multi-Client, Multi-Service Public Accounting Firm. Berkeley, CA: The Law \& Economics Consulting Group Inc.

Arrunada, B. (1999). The Economics of Audit Quality: Private Incentives and the Regulation of Audit and Non-Audit Services. Dordrecht, The Netherland: Kluwer Academics Publishers.

Barkess, L., \& Simnett, R. (1994). The Provision of Other Services by Auditors: Independence and Pricing Issues. Accounting and Business Research, 24(94), 99-108. http://dx.doi.org/10.1080/00014788.1994.9729469

Beattie, V., \& Fearnley, S. (2002). Auditor Independence and Non-Audit Services: A Literature Review. Retrieved from http://www.icaew.com (visited on 10th of September, 2008)

Beattie, V., Fearnley, S., \& Brandt, R. (2001). Behind Closed Doors: What Company Audit is Really About. New York: Palgrave. http://dx.doi.org/10.1057/9780230599413

Beck, P. J., Frecka, T. J., \& Solomon, I. (1988). A model of the market for MAS and audit services: knowledge spillovers and auditor-auditee bonding. Journal of Accounting Literature, 7, 50-64.

Brandon, D. M., Crabtree, A. D., \& Maher, J. J. (2004). Non-audit fees, Auditor Independence and Bond Ratings. Auditing: A Journal of Theory \& Practice, 23(2), 89-103. http://dx.doi.org/10.2308/aud.2004.23.2.89

Canning, M., \& Gwilliam, D. (1999). Non-Audit Services and Auditor Independence: Some Evidence from Ireland. The European Accounting Review, 8(3), 401-419. http://dx.doi.org/10.1080/096381899335853 
Chung, H., \& Kallapur, S. (2003). Client Importance, Non-Audit Services, and Abnormal Accruals. The Accounting Review, 78(4), 931-955. http://dx.doi.org/10.2308/accr.2003.78.4.931

Clikeman, P. (1998). Auditor Independence: Continuing Controversy. Ohio CPA Journal, 57(2), 40-43.

Craswell, A. T. (1999). Does the Provision of Non-Audit Services Impair Auditor Independence? International Journal of Auditing, 3(1), 29-40.

DeAngelo, L. E. (1981a). Auditor Size and Audit Quality. Journal of Accounting and Economics, 3, 183-199. http://dx.doi.org/10.1016/0165-4101(81)90002-1

DeAngelo, L. E. (1981b). The Auditor-Client Contractual Relationship: An Economic Analysis. USA: UMI Research Press.

DeBerg, C., \& Pany, K. (1991). An Examination of Some Relationships between Non-Audit Services and Auditor Change. Accounting Horizons, 5(1), 17-28.

DeFond, M., Raghunandan, K., \& Subramanyam, K. (2002). Do Non-Audit Service Fees impair Auditor Independence? Evidence from Going-concern Audit Opinions. Journal of Accounting Research, 40(4), 1247-1274. http://dx.doi.org/10.1111/1475-679X.00088

Fearnley, S., Brandt, R., \& Beattie, V. (2005). Auditor Independence and Audit Risk: A Reconceptualisation. Journal of International Accounting Research, 4, 39-71. http://dx.doi.org/10.2308/jiar.2005.4.1.39

Felix J. W. L., Gramling, A. A., \& Maletta, M. J. (2005). The Influence of Non-Audit Service Revenues and Client Pressure on External Auditors' Decisions to Rely on Internal Audit. Contemporary Accounting Research, 22(1), 31-53. http://dx.doi.org/10.1506/JN7X-B51L-V45W-4U7R

Firth, M. (1997a). The Provision of Non-Audit Services and the Pricing of Audit Fees. Journal of Business Finance and Accounting, 24(3/4), 511-525. http://dx.doi.org/10.1111/1468-5957.00118

Firth, M. (1997b). The Provision of Non-Audit Services by Accounting Firms to their Audit Clients. Contemporary Accounting Research, 14(2), 1-21. http://dx.doi.org/10.1111/j.1911-3846.1997.tb00524.x

Firth, M. (2002). Auditor Provided Consultancy Services and their Associations with Audit Fees and Audit Opinions. Journal of Business Finance and Accounting, 29(5/6), 661-693. http://dx.doi.org/10.1111/1468-5957.00446

Flint, D. (1988). Philosophy and Principles of Auditing: An Introduction. London: Macmillan Education Ltd.

Francis, J. R. (2006). Are Auditors Compromised by Nonaudit Services? Assessing the Evidence. Contemporary Accounting Research, 23(3), 747-760. http://dx.doi.org/10.1506/4VD9-AE3K-XV7L-XT07

Frankel, R., Johnson, M., \& Nelson, K. (2002). The Relation between Auditors' Fees for Non-Audit Services and Earnings Management. The Accounting Review, 77(4, supplement), 77-105.

Gaynor, L., McDaniel, L., \& Neal, T. (2006). The Effects of Joint Provision and Disclosure of Non-audit Services on Audit Committee Members' Decisions and Investors' Preferences. The Accounting Review, 81(4), 873-986. http://dx.doi.org/10.2308/accr.2006.81.4.873

Glezen, G. W., \& Millar, J. A. (1985). An Empirical Investigation of Stockholder Reaction to Disclosures Required by ASR No. 250. Journal of Accounting Research, 23, 859-870. http://dx.doi.org/10.2307/2490843

Goldman, A., \& Barlev, B. (1974). The Auditor-firm Conflict of Interests: its Implications for Independence. The Accounting Review, October, 707-718.

Grout, P., Jewitt, I., Pong, C., \& Whittington, G. (1994). Auditor Professional Judgement: Implications for Regulations and the Law. Economic Policy, 9, 308-351. http://dx.doi.org/10.2307/1344498

Gul, F. A. (1989). Bankers' Perceptions of Factors Affecting Auditor Independence. Journal of Accounting, Auditing and Accountability, 2(3), 40-51. http://dx.doi.org/10.1108/09513578910132303

Hartley, R. V., \& Ross, T. L. (1972). MAS and Audit Independence: an Image Problem. Journal of Accountancy, November, 42-51.

Hasan, S. A. (2000). Indications to Audit Quality. Journal of Economic and Business, 35(2), 203.

Hay, D., Knechel, R., \& Li, V. (2006). Non-audit Services and Auditor Independence: New Zealand Evidence. $\begin{array}{llll}\text { Journal of Business Finance \& Accounting, } & 33(5 / 6), & \text { 715-734. }\end{array}$ http://dx.doi.org/10.1111/j.1468-5957.2006.00602.x

Hillison, W., \& Kennelly, M. (1988). The Economics of Non-Audit Services. Accounting Horizons, 2(3), 32-40. 
Humphrey, C. (1997). Debating Audit Expectations (2nd ed., pp. 3-30). London: Paul Chapman.

Jenkins, J. G., \& Krawczyk, K. (2001). The Relationship between Non-Audit Services and Perceived Auditor Independence. SSRN Working Paper. Retrieved from http://www.ssrn.com [accessed 04th January 2008]

Jensen, M. C., \& Meckling, W. H. (1976). Theory of the Finn: Managerial Behaviour, Agency Costs and Ownership Structure. Journal of Financial Economics, 3(4), 305-360. http://dx.doi.org/10.1016/0304-405X(76)90026-X

Largay, J. (2002). Lessons from Enron. Accounting Horizons, 16(2), 153-156. http://dx.doi.org/10.2308/acch.2002.16.2.153

Lee, T. A. (1993). Corporate Audit Theory. Devon: Chapman and Hall.

Lennox, C. (1999). Are large auditors more accurate than small auditors? Accounting \& Business Research, 29(3), 217-227. http://dx.doi.org/10.1080/00014788.1999.9729582

Lowe, D. J., \& Pany, K. (1995). CPA Performance of Consulting Engagements with Audit Clients: Effects on Financial Statement Users' Perceptions and Decisions Auditing. A Journal of Practice \& Theory, 14(2), 35-53.

Magee, R. P., \& Tseng, M. C. (1990). Audit Pricing and Independence. The Accounting Review, 65(2), 315-336.

Mautz, R. K., \& Sharaf, H. A. (1961). The Philosophy of Auditing. American Accountants Association, USA.

Mikol, A., \& Standish, P. (1998). Audit Independence and Non-Audit Services: a Comparative Study in Differing British and French perspectives. The European Accounting Review, 7(3), 541-569. http://dx.doi.org/10.1080/096381898336411

Mitra, S. (2007). Non-audit Services Fees and Auditor Independence: Empirical Evidence from the Oil and Gas Industry. Journal of Accounting, Auditing and Finance, 22(1), 85-107.

Moizer, P. (1997). Independence. In Sherer, M., \& Turley, S. (Eds.), Current Issues in Auditing (3rd ed.). London: Paul Chapman Publishing.

Palmrose, Z. V. (1986a). Audit Fees and Auditor size: Further Evidence. Journal of Accounting Research, 24(1), 97-110. http://dx.doi.org/10.2307/2490806

Palmrose, Z. V. (1986b). The Effect of Non-Audit Services on the Pricing of Audit Services: Further Evidence. Journal of Accounting Research, 24(2), 405-411. http://dx.doi.org/10.2307/2491144

Palmrose, Z. V. (1988). An Analysis of Auditor Litigation and Audit Service Quality. The Accounting Review, 63, 55-73.

Palmrose, Z. V. (1989). The Relation of Audit Contract Type to Audit Fees and Hours. The Accounting Review 64(3), 488-499.

Patten, R. J., \& Nuckols, J. R. (1978). Competence and Independence: The Issue of Management Services. London: John Wiley and Sons.

Quick, R., \& Ben-Rasmussen, W. (2005). The Impact of MAS on Perceived Auditor Independence - Some Evidence from Denmark. Accounting Forum, 29, 137-168. http://dx.doi.org/10.1016/j.accfor.2004.09.001

Raghunandan, K. (1993). Predictive Ability of Audit Qualifications for Loss Contingencies. Contemporary Accounting Research, 9(Spring), 612-634. http://dx.doi.org/10.1111/j.1911-3846.1993.tb00900.x

Raghunandan, K. (2003). Non-Audit Services and Shareholder Ratification of Auditor's Appointments. Auditing: A Journal of Practice \& Theory, 22(1), 155-163. http://dx.doi.org/10.2308/aud.2003.22.1.155

Remenyi, D., Williams, B., Money, A., \& Swartz, E. (2002). Doing Research in Business and Management. London: SAGE Publications.

Santan, M. (2007). Non-Audit Service Fees and Auditor Independence: Empirical Evidence from the Oil and Gas Industry (Sole-author). Journal of Accounting Auditing and Finance, 85-107.

Saunders, M., Lewis, P., \& Thornhill, A. (2007). Research Methods for Business Students (4th ed.). Prentice Hall.

Scheiner, J. H. (1984). An Empirical Assessment of the Impact of SEC Non-Audit Service Disclosure Requirements on Independent Auditors and their Clients. Journal of Accounting Research, 22(2), 789-797. http://dx.doi.org/10.2307/2490682

Shockley, R. A. (1981). Perceptions of Auditors' Independence: An Empirical Analysis. The Accounting Review, 
56(4), 785-800.

Simunic, D. A. (1984). Auditing, Consulting, and Auditor Independence. Journal of Accounting Research, 22(2), 679-702. http://dx.doi.org/10.2307/2490671

Sori, Z. M. (2005). An Investigation into Auditor Independence, Non-Audit Services and Corporate Governance Issues in Malaysia. Unpublished PhD Thesis, Cardiff University.

Svanström, T., \& Sundgren, S. (2012). The Demand for Non-Audit Services and Auditor-Client Relationships: Evidence from Swedish Small and Medium-Sized Enterprises. International Journal of Auditing, 16, 54-78. http://dx.doi.org/10.1111/j.1099-1123.2011.00441.x

Wallman, S. M. H. (1996). The Future of Accounting, part III: Reliability and Auditor Independence. Accounting Horizons, 10(4), 76-97.

Wines, G. (1994). Auditor Independence, Audit Qualifications and the Provision of Non-Audit Services: a note. Accounting and Finance, 34, 75-86. http://dx.doi.org/10.1111/j.1467-629X.1994.tb00263.x

\section{Copyrights}

Copyright for this article is retained by the author(s), with first publication rights granted to the journal.

This is an open-access article distributed under the terms and conditions of the Creative Commons Attribution license (http://creativecommons.org/licenses/by/3.0/). 